\title{
Hypothalamic Hypocretin (Orexin): Robust Innervation of the Spinal Cord
}

\author{
Anthony N. van den Pol \\ Department of Neurosurgery, Yale University School of Medicine, New Haven, Connecticut 06520
}

Hypocretin (orexin) is synthesized by neurons in the lateral hypothalamus and has been reported to increase food intake and regulate the neuroendocrine system. In the present paper, long descending axonal projections that contain hypocretin were found that innervate all levels of the spinal cord from cervical to sacral segments, as studied in mouse, rat, and human spinal cord and not previously described. High densities of axonal innervation are found in regions of the spinal cord related to modulation of sensation and pain, notably in the marginal zone (lamina 1). Innervation of the intermediolateral column and lamina 10 as well as strong innervation of the caudal region of the sacral cord suggest that hypocretin may participate in the regulation of both the sympathetic and parasympathetic parts of the autonomic nervous system. Doublelabeling experiments in mice combining retrograde transport of diamidino yellow after spinal cord injections and immunocyto- chemistry support the concept that hypocretin-immunoreactive fibers in the cord originate from the neurons in the lateral hypothalamus. Digital-imaging physiological studies with fura-2 detected a rise in intracellular calcium in response to hypocretin in cultured rat spinal cord neurons, indicating that spinal cord neurons express hypocretin-responsive receptors. A greater number of cervical cord neurons responded to hypocretin than another hypothalamo-spinal neuropeptide, oxytocin. These data suggest that in addition to possible roles in feeding and endocrine regulation, the descending hypocretin fiber system may play a role in modulation of sensory input, particularly in regions of the cord related to pain perception and autonomic tone.

Key words: hypothalamus; neuroendocrine; spinal cord; autonomic nervous system; pain; food intake; energy regulation; lamina 1
We recently reported a new hypothalamic peptide, hypocretin, in neurons of the lateral hypothalamus-perifornical region (de Lecea et al., 1998). On the basis of immunocytochemistry, in situ hybridization, and Northern blots, synthesis of the peptide was restricted to cell bodies in the lateral hypothalamic region of the brain and not elsewhere (Gautvik et al., 1996; de Lecea et al., 1998; Sakurai et al., 1998; van den Pol et al., 1998). Injections of this peptide, also called orexin, into the brain caused rats to increase their food intake; food restriction caused an increase in peptide synthesis, suggesting a role for the peptide in energy metabolism (Sakurai et al., 1998). Innervation of the arcuate nucleus and electrophysiological responses of identified neuroendocrine neurons suggested that the peptide might also be involved in regulation of the neuroendocrine system (van den Pol et al., 1998). This is consistent with the finding of a large number of hypocretin axons in synaptic contact with neuropeptide $\mathrm{Y}$ cells of the arcuate nucleus, suggesting that the activity of the hypothalamic neuropeptide Y system may be modulated by hypocretin (Horvath et al., 1999). The region of the brain with the highest density of hypocretin-containing neurons, the lateral hypothalamus, has been implicated in control of feeding, arousal, and autonomic control relating to both sympathetic and parasympathetic systems. Hypocretin-immunoreactive axons project to many regions of the brain, including the nucleus of the solitary tract, dorsal motor nucleus of the vagus, and multiple hypotha-

\footnotetext{
Received Dec. 10, 1998; revised Jan. 29, 1999; accepted Jan. 29, 1999.

I thank Dr. C. LaMotte for helpful suggestions and Dr. Y. Yang and J. Belousova for excellent technical assistance.

Correspondence should be addressed to Anthony N. van den Pol, Department of Neurosurgery, Yale University School of Medicine, 333 Cedar Street, New Haven, CT 06520.

Copyright (C) 1999 Society for Neuroscience $\quad 0270-6474 / 99 / 193171-12 \$ 05.00 / 0$
}

lamic nuclei (Peyron et al., 1998), regions that may contribute to the regulation of the autonomic nervous system.

Ultrastructural analysis demonstrates that within axon terminals, hypocretin is probably localized to dense core vesicles, suggesting a possible transmitter function (de Lecea et al., 1998). Two receptors have been cloned that respond to hypocretin (Sakurai et al., 1998), further substantiating a transmitter role for the peptide. Whole-cell recordings in culture show that hypocretin increases synaptic activity (de Lecea et al., 1998). Hypocretin acts both on postsynaptic receptors to increase cytosolic calcium and on presynaptic receptors to enhance release of amino acid neurotransmitters (van den Pol et al., 1998). The hypocretin gene localizes to chromosome 17q21 (de Lecea et al., 1998; Sakurai et al., 1998), a region that has been implicated in some forms of rare but severe human brain disease (Wilhelmsen et al., 1994; Wijker et al., 1996). Hypocretin projections to the spinal cord have not previously been described. In the present study, long descending axons that contain hypocretin immunoreactivity were found innervating all levels of the spinal cord. Both immunocytochemistry with normal and colchicine-treated rats and in situ hybridization studies have located hypocretin-positive cells only in the lateral hypothalamic area. Based on this and on double labeling with retrograde tracers and immunostaining, the hypocretinimmunoreactive axons in the spinal cord appear to originate only from these neuronal cell bodies in the hypothalamus.

\section{MATERIALS AND METHODS}

Immunocytochemistry. Six- to 8-week-old rats (albino Sprague Dawley, $n=5$ ) and mice (Swiss Webster background, $n=12$ ) were anesthetized with sodium pentobarbital $(80 \mathrm{mg} / \mathrm{kg})$ and perfused transcardially with a fixative containing $4 \%$ paraformaldehyde and $0.1 \%$ glutaraldehyde in 0.1 $\mathrm{M}$ phosphate buffer. Sections were cut either on a vibratome at a thick- 

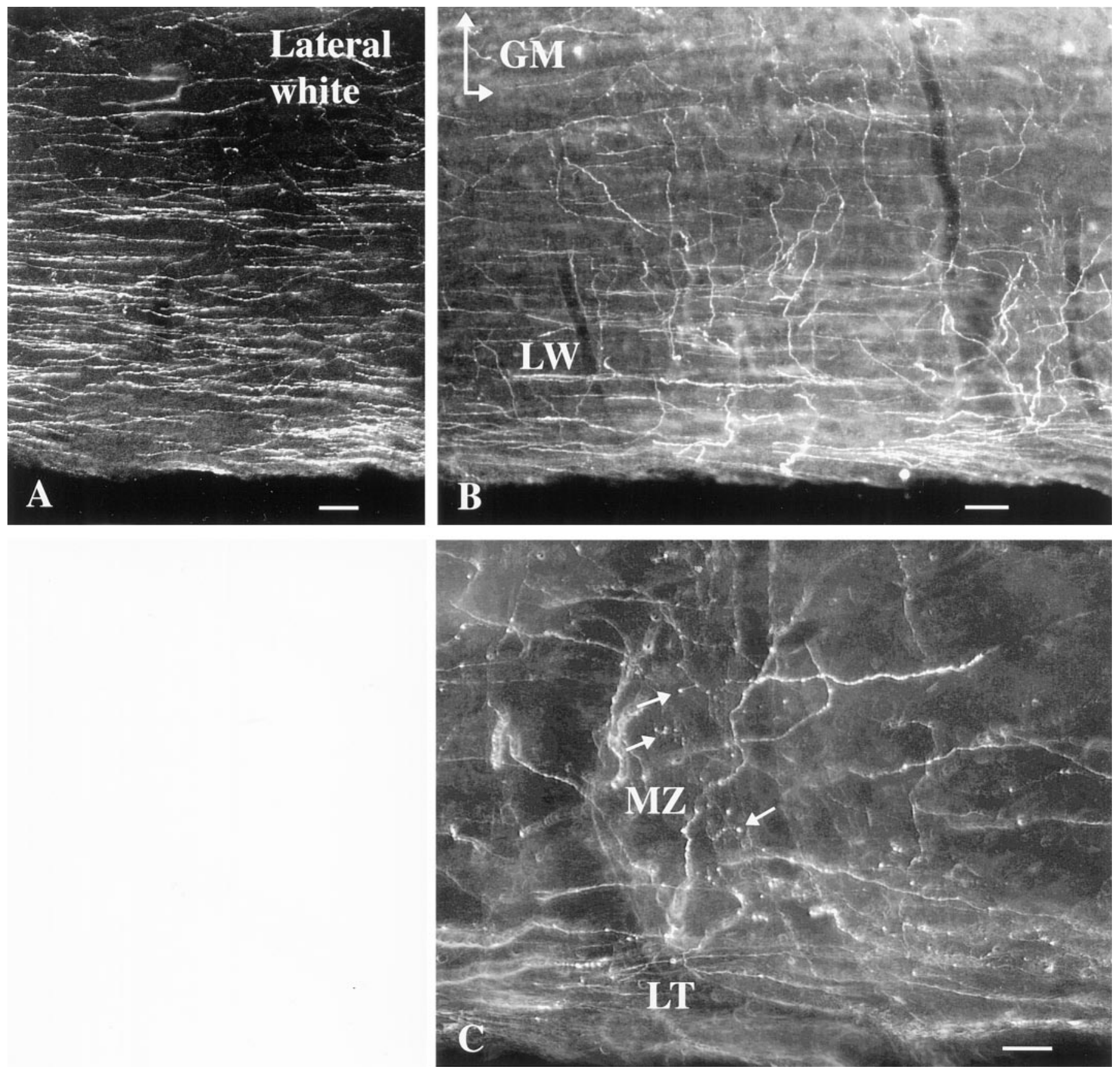

Figure 1. Hypocretin-immunoreactive axons in rat white matter, horizontal section. $A$, In the dorsal region of the lateral white matter, a high density of immunoreactive axons is found in this dark-field micrograph. $B$, More ventrally in the lateral white matter $(L W)$, some axons turn medially to enter the gray matter $(G M, t o p)$. $C$, In the dorsal part of the cord in the region of Lissauer's tract $(L T)$, some axons leave a group of descending axons at the bottom and enter into part of the marginal zone $(M Z)$ where boutons are found (arrows). Scale bars: $A, 30 \mu \mathrm{m} ; B, 25 \mu \mathrm{m} ; C, 15 \mu \mathrm{m}$.

ness of 30-50 $\mu \mathrm{m}$ or on a cryostat at $20-30 \mu \mathrm{m}$. After washing in normal buffer containing $0.1 \%$ lysine, $1 \%$ bovine serum albumin, $1 \%$ normal goat serum, and $0.3 \%$ Triton X-100, sections were incubated overnight in primary rabbit antiserum against the neuroactive peptide hypocretin-2. After washing in buffer, sections were incubated in biotinylated goat anti-rabbit Ig, washed, and then treated with avidin-biotin-peroxidase complex (Vector Laboratories, Burlingame, CA), as described in greater detail elsewhere (van den Pol, 1985). Sections were then reacted with diaminobenzidine and hydrogen peroxide to reveal the horseradish peroxidase complex. Some sections were counterstained with neutral red to reveal spinal cord cells. Most of the analysis was done with cross-sections, but some series of sections were also cut in horizontal or sagittal planes.

Human tissue $(n=2)$ was obtained within $10-18 \mathrm{hr}$ after death. Death was caused by cardiac arrest. Subjects were 50-70 years old. Slices of cervical cord were immersed in Bouin's fixative for several days and then cut on a cryostat in $30-50 \mu \mathrm{m}$ sections.

The primary hypocretin antiserum used binds to the neuroactive peptide hypocretin-2, as described in detail elsewhere (van den Pol et al., 1998). Control adsorption with the antigen blocked staining, as did elimination of incubation in primary antiserum. Both immunoperoxidase and immunofluorescence gave similar patterns of staining. Use of a second antiserum raised in a different rabbit against hypocretin- 2 also gave similar patterns of staining. Furthermore, a third antiserum (a generous gift from Drs. T. Kilduff, G. Sutcliffe, and L. de Lecea, Scripps Research Institute, La Jolla, CA) raised against the preprohypocretin sequence (de Lecea et al., 1998) showed similar patterns of immunoreactive axons in the spinal cord, as described in Results.

Tissue culture. To determine whether spinal cord neurons showed a 

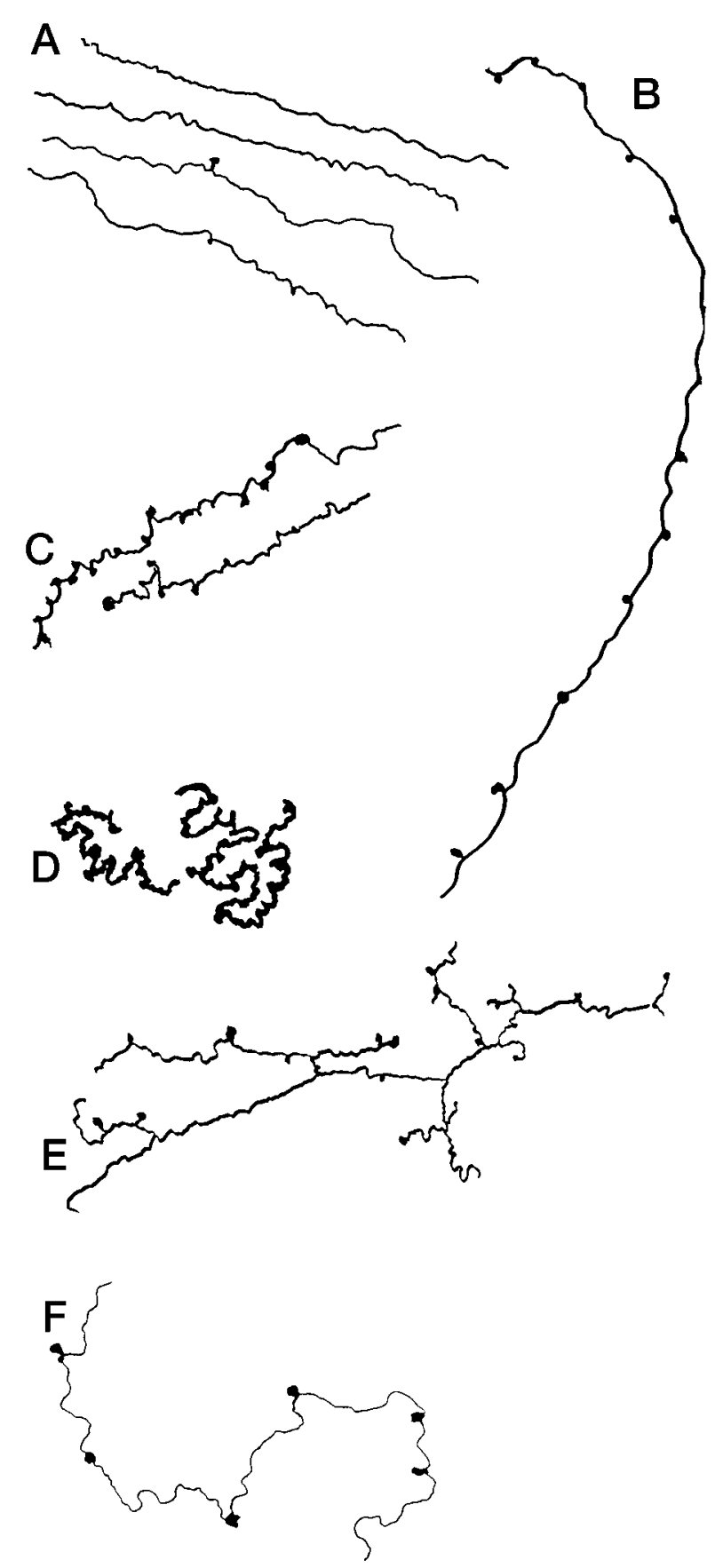

Figure 2. Hypocretin axons with a variety of shapes in rat cord. A, Thin parallel axons entering the gray matter from the dorsolateral white matter. $B$, Long axons descend from lamina $3 / 4$ down to lamina 7 with boutons at regular intervals in each lamina the axon traverses. $C$, Axons may traverse the intermediolateral column with frequent boutons. $D$, Some axons are thick with large numbers of tightly packed boutons investing a small region of lamina 5. E, Lateral to the central canal, axons have frequent branches. $F$, In the ventral horn, thin axons maintain only a few boutons. Scale bar, $20 \mu \mathrm{m}$.

physiological response to hypocretin, cultures were made from embryonic day 18 rat spinal cords. The cervical cord was removed and cultured as previously described for other regions of the CNS (van den Pol et al., 1998). Cells were plated on glass coverslips precoated with poly-L-lysine

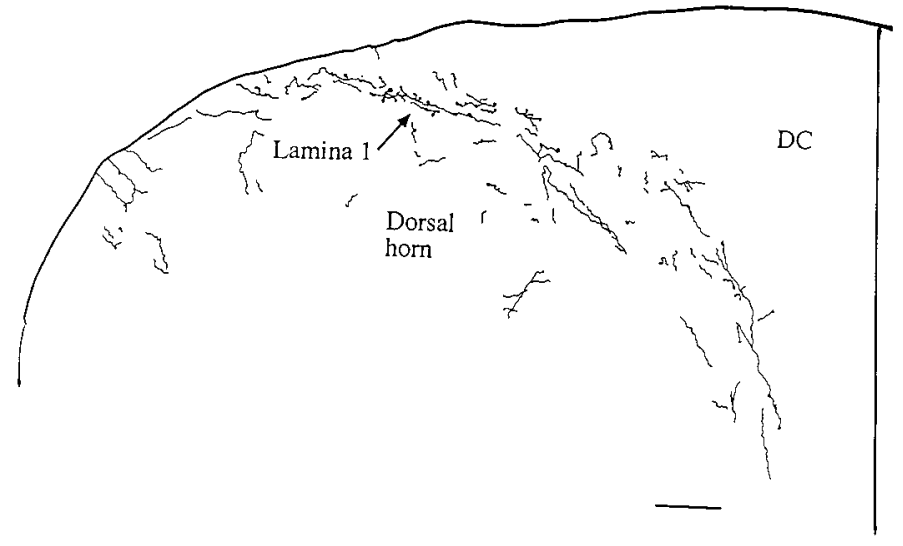

Figure 3. Lamina 1 of the dorsal horn in rat. A single $50-\mu \mathrm{m}$-thick section was used to trace hypocretin-immunoreactive axons in a crosssection of the midcervical dorsal horn. Boutons were particularly prevalent in lamina 1. $D C$, Dorsal columns. Scale bar, $70 \mu \mathrm{m}$.

(540 kDa; Collaborative Research, Bedford, MA) and allowed to grow for 7-12 $\mathrm{d}$ before being used for digital imaging.

Calcium digital imaging. Cultures were loaded with fura-2 AM (5 $\mu \mathrm{M}$; Molecular Probes, Eugene, OR) and studied on a Nikon (Tokyo, Japan) Diaphot microscope with objectives that passed $340 \mathrm{~nm}$ light (Olympus Optical, Tokyo, Japan; 40×) using a $150 \mathrm{~W}$ xenon bulb for illumination. Light was controlled by a Lambda 10 filter wheel (Sutter Instruments, Novato, CA) interfaced with a lab computer. Software from Universal Imaging (Media, PA; Image 1/Fluor) was used to collect data, which was then analyzed off-line with Igor Pro software (WaveMetrics, Lake Oswego, OR). The equation developed by Grynkiewicz et al. (1985) was used to determine relative cytosolic calcium levels. During imaging, coverslips were loaded into a laminar flow chamber (Forscher et al., 1987) that had a volume of $\sim 180 \mu \mathrm{l}$ and eight inlet ports that allowed switching between different agonists. Details of fura-2 calcium digital imaging are described elsewhere (van den Pol et al., 1996, 1998; Obrietan and van den Pol, 1997). Hypocretin-2 was made in-house and purified to 98\% purity; the same peptide was used for generating the antisera for immunocytochemistry and for the physiological studies with calcium imaging. Physiological studies with hypocretin-1 were done with the peptide sequence described by Sakurai et al. (1998), and this peptide was obtained from Phoenix Pharm (Mountain View, CA).

Most photomicrographs here were taken with a Spot-2 digital camera (Diagnostic Instruments, Sterling Heights, MI) in the monochrome mode. Some were taken with film, and the film was digitally scanned with a Polaroid (Waltham, MA) film scanner. Images were printed on an Eastman Kodak (Rochester, NY) 8650 dye sublimation printer. In some micrographs, a dark-field condenser was used, and in some the immunoreactive fibers were illuminated by fiber optics through the side of the glass slide. Contrast and gray scale were digitally corrected.

Retrograde transport studies. To ensure that hypocretin axons in the spinal cord arose from hypothalamic origins, the fluorescent dye diamidino yellow (Sigma, St. Louis, MO) was injected into six to eight regions of the cervical and thoracic cord of five mice by microinjections with a Hamilton (Reno, NV) microsyringe. Two to $4 \mathrm{~d}$ after injections, mice were anesthetized as above and perfused with $4 \%$ paraformaldehyde. Forty micrometer sections were cut in the lateral hypothalamus, and hypocretin-immunoreactive cell bodies were immunostained with Alexa546 goat anti-rabbit Ig.

\section{RESULTS}

\section{White matter}

In both rat and mouse, hypocretin-immunoreactive axons descended the entire length of the cord, with the highest concentration of descending axons in the dorsal region of the lateral white matter (Fig. $1 A$ ). Long descending immunoreactive axons were most clear in horizontal and sagittal sections of the cord but could also be found in cross-sections. In single sections, hundreds of immunoreactive axons could be found traveling in this region 

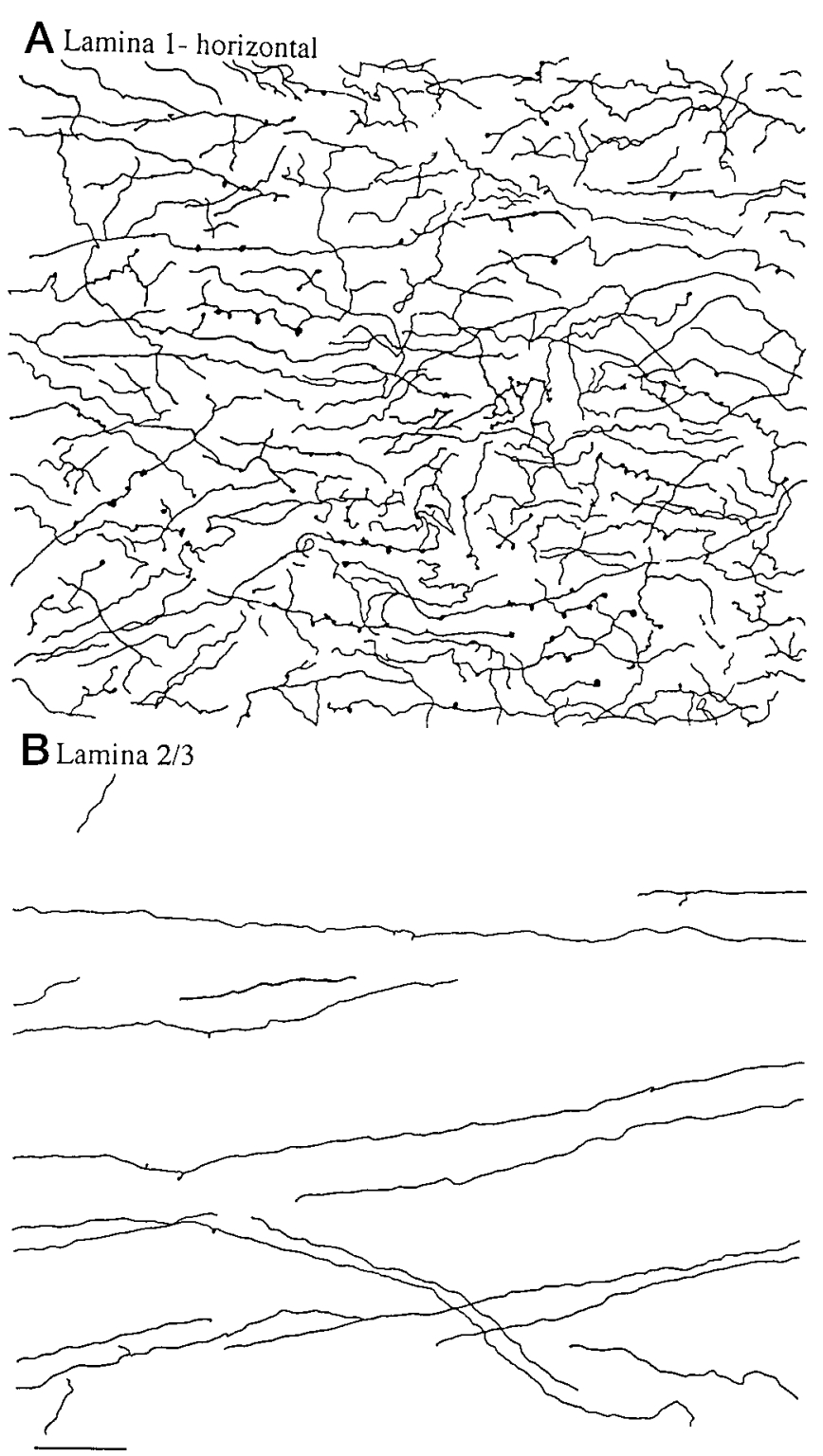

Figure 4. Dorsal horn, horizontal sections in rat. $A$, A substantial number of hypocretin-immunoreactive axons are found in $40-\mu \mathrm{m}$-thick horizontal sections of the midcervical cord, shown here from camera lucida drawings. $B$, In contrast to the marginal zone above, in laminae 2 and 3 , relatively few axons are found, and those that do appear show little branching and few boutons. Both regions were drawn with the same size dimensions. Scale bar, $45 \mu \mathrm{m}$.

of the white matter (Fig. 1). More ventrally in the lateral white matter, descending axons ran parallel with the long axis of the cord and often turned medially to enter the gray matter (Fig. 1B). A low density of isolated axons were found in all other regions of the white matter also, often oriented in a radial manner, parallel with large dendrites that protrude from the gray matter into the white matter in lateral and ventral white matter. In the dorsal cord, some descending axons entered the cord via Lissauer's tact (Fig. 1C). Occasional solitary axons were found traversing the dorsal columns in all levels of the cord. This was particularly common in the sacral cord where the dorsal columns are relatively small. Axons were medium-size in the white matter, with a diameter of 1-2 $\mu \mathrm{m}$. When turning medially and entering the gray matter, axonal diameter ranged from 2 down to $0.2 \mu \mathrm{m}$.

\section{Gray matter}

Immunoreactive axons were found in all 10 laminae of the cord, with a higher level of innervation in the dorsal and midline cord than in the ventral horn. Identification of the laminae of the spinal cord was facilitated by descriptions by Molander et al. (1984, $1989)$ in rodents, patterned after Rexed's work on the cat (1952, 1954). At any particular level of the cord, both large and small immunoreactive boutons were found, with large boutons approaching $3 \mu \mathrm{m}$ diameter and small ones of $0.5 \mu \mathrm{m}$ diameter. In some regions, thin axons with a fixed diameter appeared to pass through, with little indication of boutons (Fig. $2 A$ ). In others, frequent boutons en passant (Fig. $2 B, C, D, F$ ) and termineaux (Fig. $2 E$ ) were identified. Whereas in the white matter axons maintained a more homogeneous size, in the gray matter a wide variety of thick and thin shapes and diameters were adopted (Fig. 2), suggesting that the local milieu may play a role in determining the local shape of these axons. In the same section, axons included those that showed a paucity of boutons and a diameter of $<1 \mu \mathrm{m}$ (Fig. $2 A$ ), axons that were unbranched and fairly straight and run over long distances through several laminae with large numbers of boutons at regular intervals (Fig. 2B), thick axons with a diameter approaching $2.5 \mu \mathrm{m}$ with large numbers of boutons (Fig. $2 D$ ), axons that showed a substantial number of branches (Fig. $2 E$ ), and thin axons that tended to wander with intermittent and infrequent boutons.

\section{Dorsal horn}

Throughout the entire length of the spinal cord in rats and mice, the dorsal horn received a proliferation of immunoreactive fibers (Figs. 3, 4). Within the dorsal horn, lamina 1 received the strongest innervation (Fig. 3), with immunoreactive axons surrounding lamina 1 cells that have a slightly elliptical cell body that is oriented parallel with the surface of the cord, or in the medial and lateral part of lamina 1, with the external border of the gray matter. Fibers had numerous boutons en passant and termineaux, characterized by asymmetrical swelling on one side of the axon. Axons were found that descended along the most superficial part of the cord over lamina 1, sometimes turning from the external localization to penetrate into lamina 1 (Fig. $1 C$ ). The true extent of the innervation of lamina 1 is best appreciated in sagittal or horizontal sections (Fig. $4 A$ ), which reveal a great abundance of hypocretin axons and a large number of boutons in single sections.

Fibers also entered laminae 2 and 3 after passing through lamina 1 , but these were not as dense as those in lamina 1 (Figs. $3,4 B)$. In the mouse, relatively few fibers were found in layers 2 and 3 of the substantia gelatinosa; in the rat there were more, but still fewer than found in lamina 1 . Some dorsal roots were also examined to determine whether any immunoreactive axons would be present there, but immunoreactivity was not found in the root. There were, however, numerous immunoreactive axons found at the dorsal root entry zone, which descended from cell bodies in the hypothalamus and turned ventrally to enter into the marginal zone of the dorsal horn.

\section{Middle cord}

Whereas there were relatively few axons in the dorsal white matter, directly under the ventral aspect of the dorsal columns and blending between the edge of the gray and white matter a number of immunoreactive axons were found (Fig. $5 B$ ). One of the strongest regions of innervation was around the central canal in lamina 10 , shown in a dark-field micrograph in Figure $5 A$. 


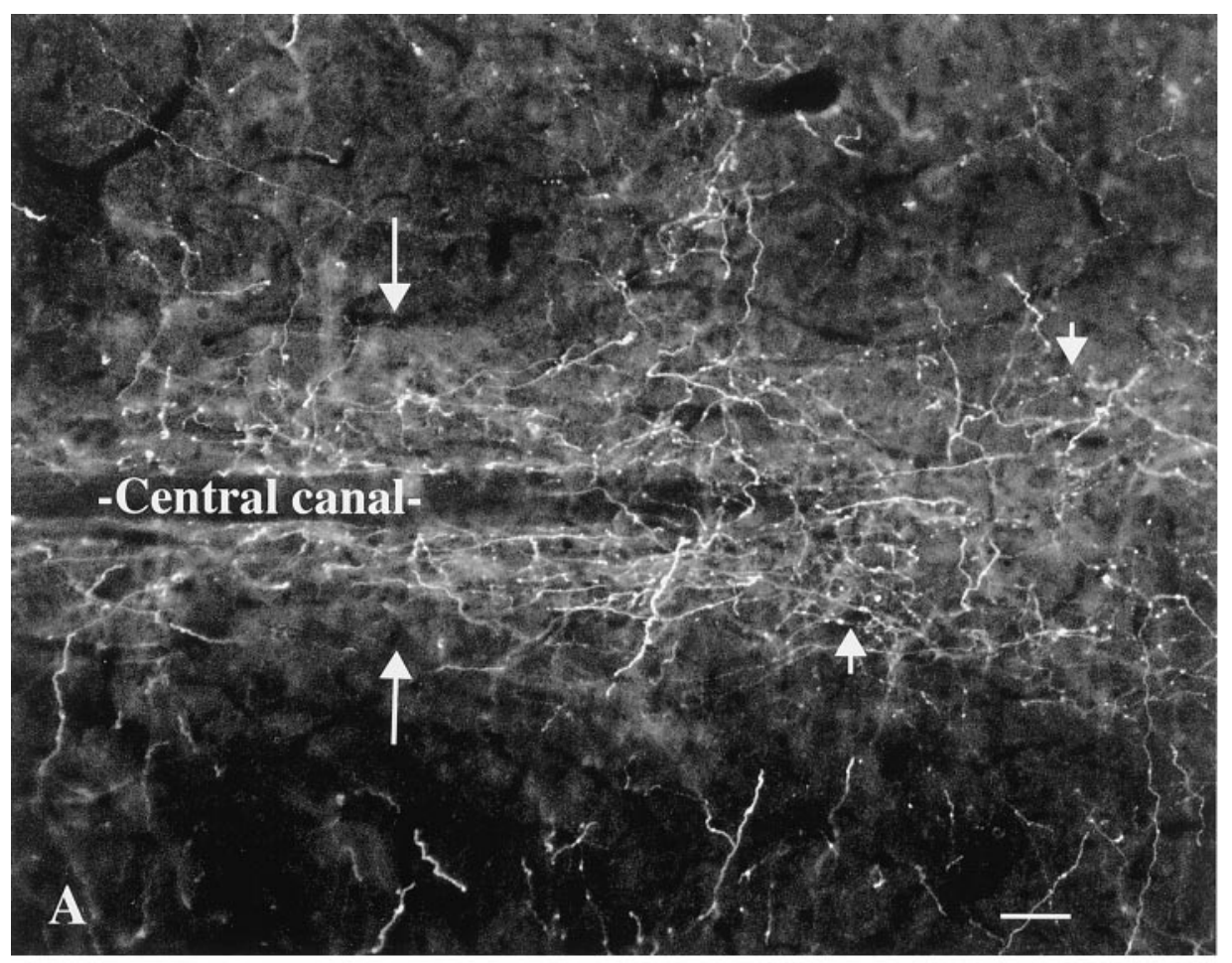

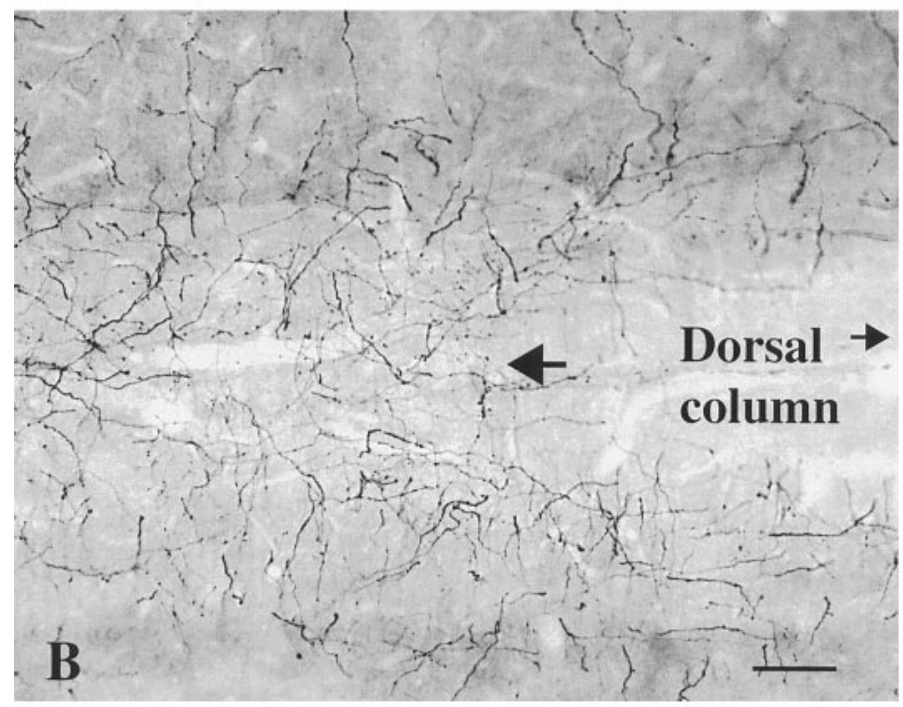

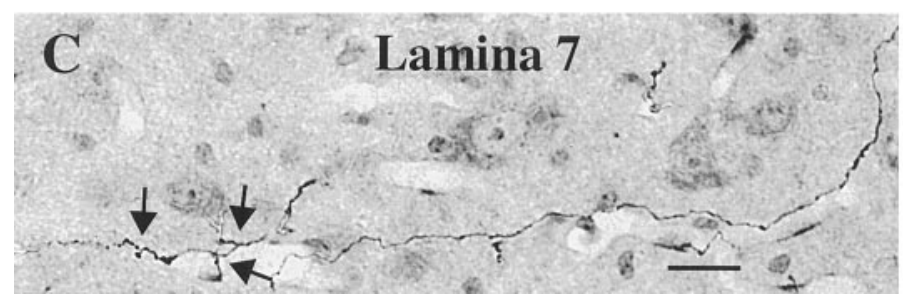

Axons here were sometimes closely associated with the ventricular ependymal cells. In some regions of the thoracic and lumbar cord, the plexus of axons in lamina 10 stretched out into the intermediomedial and intermediolateral sympathetic cell groups.

\section{Ventral horn}

Immunoreactive axons wandered through the ventral horn into laminae 7-9 (Fig. 5C). The density of axons was not high here.

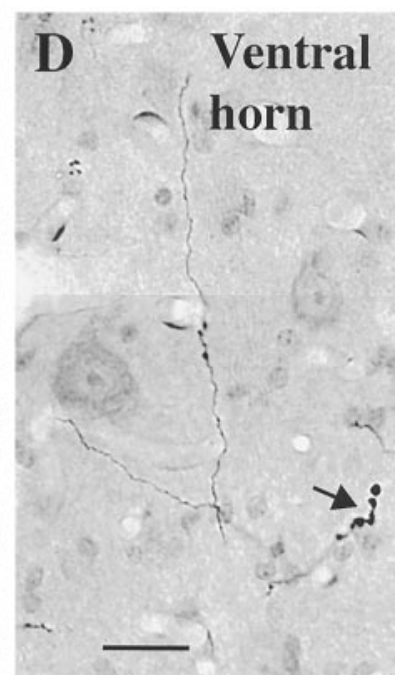

Figure 5. Hypocretin-immunoreactive axons in rat gray matter, horizontal section. $A$, In the midcord, the highest density of hypocretin-immunoreactive axons is found around the central canal (long arrows). The short arrows indicate axons in lamina 10 immediately above the central canal. $B$, At a slightly higher plane of horizontal section, the ventral aspect of the dorsal columns is seen and continues to the right in the direction of the small arrow. On the right, just under the dorsal column white matter (large arrow), the axon density increases. $C$, In lamina 7 , a hypocretin-immunoreactive axon and some of its collaterals (arrows) are found among cells stained with nuclear red. $D$, In the ventral horn, occasional axons are found, sometimes with swellings, as indicated by the arrow. Scale bars: $A, 20 \mu \mathrm{m} ; B, 22 \mu \mathrm{m} ; C, D$, $18 \mu \mathrm{m}$.

Dispersed boutons en passant and termineaux were found among different groups of cells in laminae 8 and 9 (Fig. 5D).

\section{Longitudinal innervation}

Hypocretin-immunoreactive axons with numerous boutons were found in all levels of the spinal cord from $\mathrm{C} 1$ to the caudal part of the sacral region. Differences between different segments were noted, particularly related to cell groups such as the intermedio- 


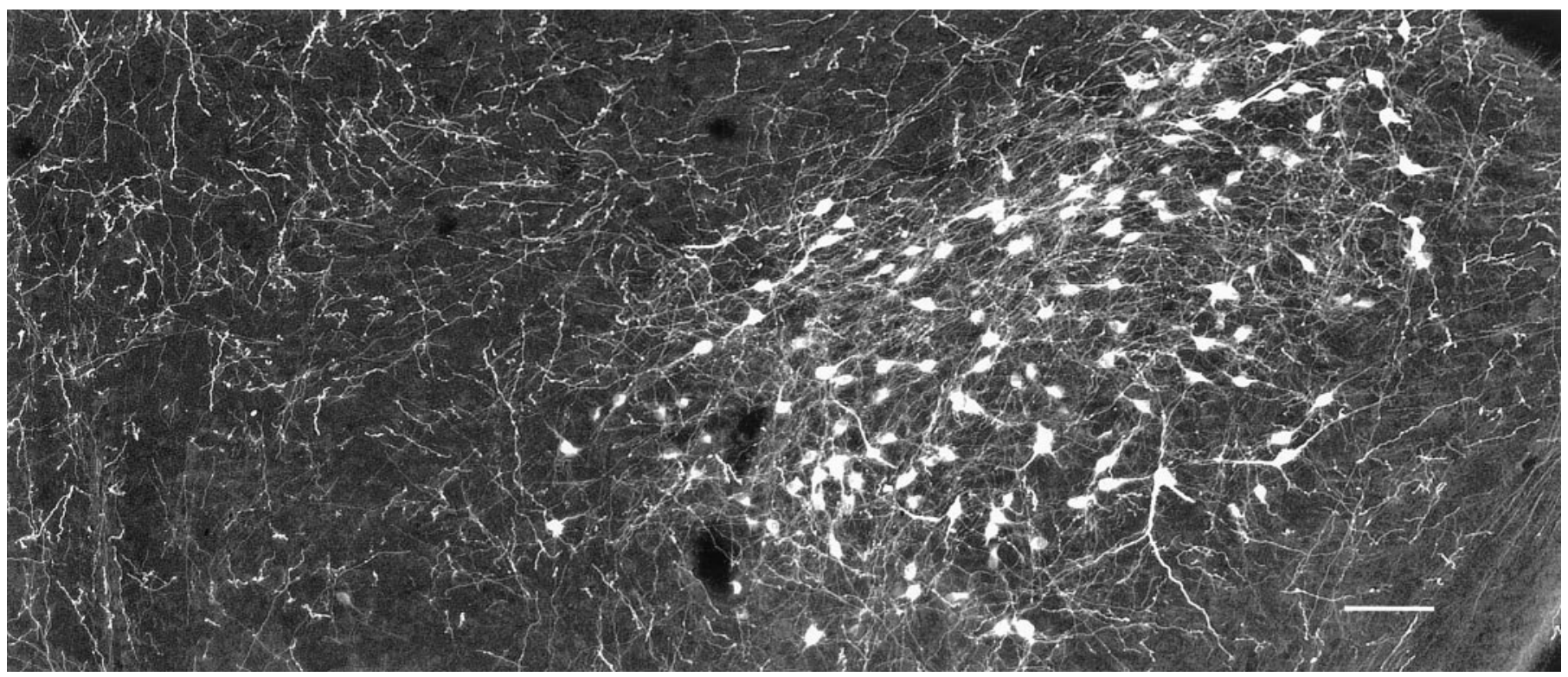

Figure 6. Hypocretin-immunoreactive perikarya in mouse. In the lateral hypothalamus and perifornical area, hypocretin-immunoreactive cell bodies and their processes are labeled. The midline is on the left, and lateral is on the right. Scale bar, $60 \mu \mathrm{m}$.

lateral column of the thoracic and lumbar cord that received hypocretin innervation. In addition, axons and boutons were found just lateral to this area in the white matter, a region where the long dendrites of these cells may extend. The highest density of fibers per segment was found in the caudal sacral spinal cord. Here the long descending axons in the dorsal region of the lateral white matter turn into the gray matter. As soon as the axons turned, boutons began to proliferate. Axons crossed the midline with high frequency and were found in all laminae, although the dorsal half of the cord was more heavily innervated than the ventral half. Camera lucida drawings from the sacral cord demonstrate the different morphological patterns that axons assume even within one segment (S3) of the cord (Fig. 2). A similar heterogeneous quality of axonal shape was found in rostral regions of the gray matter.

Hypocretin-synthesizing neurons were found in the same lateral hypothalamic area in mouse (Fig. 6) as previously described in the rat (Peyron et al., 1998). Although the rat spinal cord, being considerably larger, has more hypocretin-immunoreactive axons than the mouse, the general pattern of axonal innervation was similar in rat and mouse. The mouse spinal cord was used to construct a descending series of camera lucida drawings of the cord from $\mathrm{C} 2$ to S4. These are shown in Figures 7 and 8. In all segments shown, immunoreactive axons could be found in the superficial region of the dorsal horn and in lamina 10 around the central canal. Some of the axons that innervated lamina 10 traveled in a medial direction from the lateral white matter, and others descended through lamina 1 and continued ventrally along the interface of the lateral aspect of the dorsal columns and the gray matter before entering into and branching in lamina 10.

\section{Human spinal cord}

In the human cervical cord, the general pattern of immunoreactive fibers was similar to that of rodents. In the dorsal cord, immunoreactive axons were found at the surface of the cord (Figs. 9A,B, 10) penetrating down into Lissauer's tract, as described by Truex and Carpenter (1969). In the dorsal horn, immunoreactive axons formed a half-ring in the region of the marginal zone, shown in the micrograph in Figure $9 C$ and in the camera lucida trace in Figure 10. Both thick and thin axons traversed lamina 10 in the region of the central canal (Figs. $9 D, F-H, 10)$. One aspect of hypocretin innervation of the human cord that differed slightly from rat and mouse was the finding of immunoreactive axons that grouped together at the surface of the ventrolateral white matter in an orientation perpendicular to the outer surface of the white matter (Figs. 9E, 10).

\section{Retrograde transport from the spinal cord to the hypothalamus}

After injections of diamidino yellow in the cervical and lumbar spinal cord of mouse, hypothalamic neurons that maintained long descending projections to the cord were labeled, mostly in their cell nuclei (Fig. 11B). The nuclear label was yellow. Hypocretinimmunoreactive neurons were stained red with Alexa546. With fluorescence microscopy, neurons were found that had a red cytoplasm and yellow nuclei, indicating that they were immunoreactive for hypocretin and retrogradely transported the diamidino yellow back to the lateral hypothalamus from the spinal cord. These double-labeled cells were identified then as hypocretin-synthesizing neurons (Fig. $11 A$ ), which sent long axons to the spinal cord. In addition to cells that were doublelabeled, other cells were found that showed yellow nuclei but were not immunoreactive for hypocretin or that showed immunoreactivity for hypocretin but did not have yellow nuclei (Fig. 11). Within the field of hypocretin-immunoreactive cell bodies (Fig. 6 ), no preferential distribution of those that projected to the spinal cord was noted.

\section{Calcium responses to hypocretin in cord neurons}

We previously showed that hypocretin evokes a robust calcium rise in some hypothalamic neurons but not in hippocampal neurons, and that this calcium rise is dependent on activation of plasma membrane calcium channels (van den Pol et al., 1998). To determine whether spinal cord neurons would show any physiological response to hypocretin, the calcium response of cultured rat cervical cord neurons to hypocretin-2 was tested after at least 

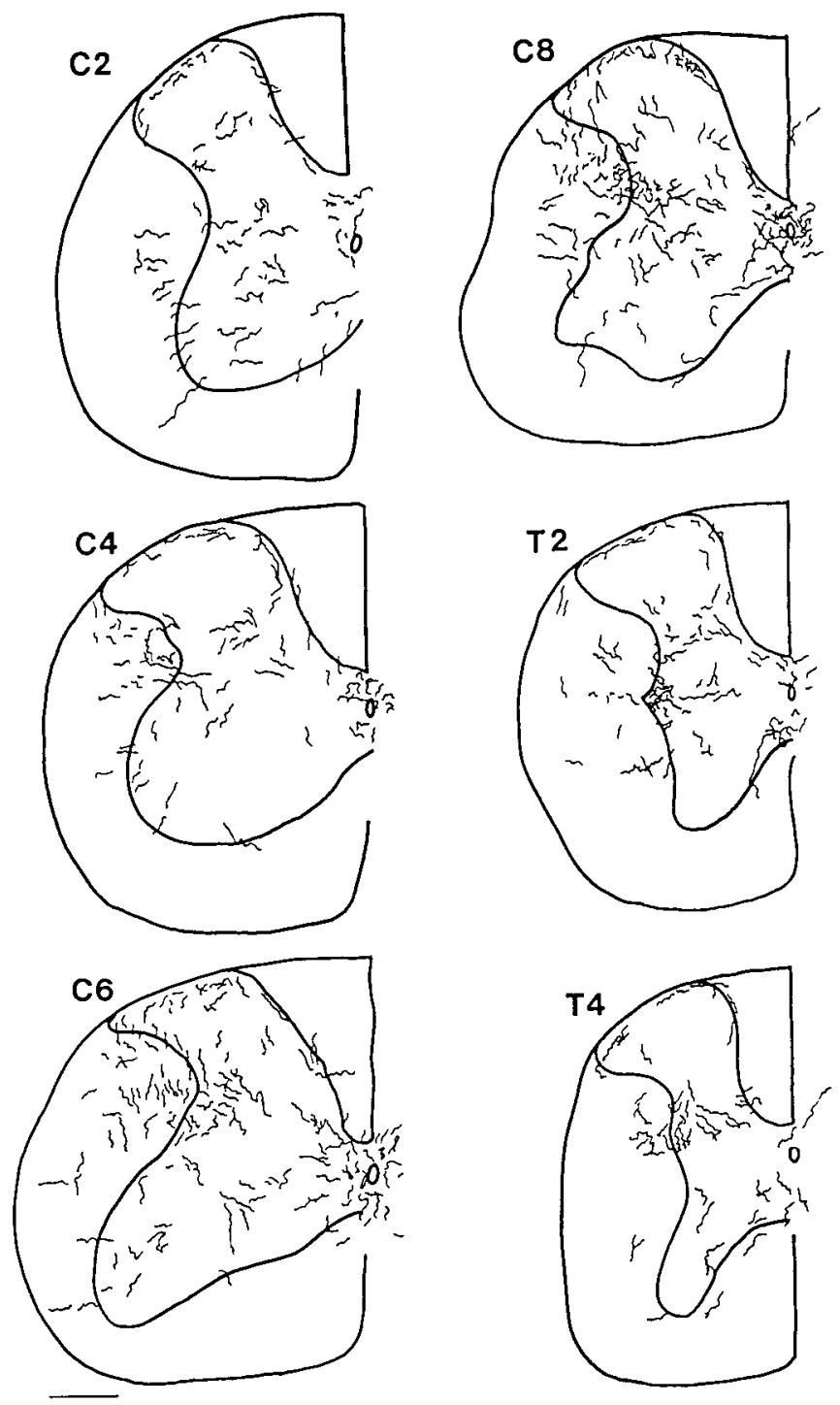

Figure 7. Hypocretin axons in mouse spinal cord, C2-T4. Camera lucida drawings were made in regular intervals from $30 \mu \mathrm{m}$ cross-sections. The outline of the cord and the outline of the gray matter are indicated by the thick lines. To allow visibility of axons when reduced in size, the diameter of the axons is greater on the drawing than it actually appeared in the microscope. Axons that were descending the cord, particularly in dorsolateral white matter, and oriented parallel with the long axis of the cord, which consequently would appear only as a single point in these crosssections, were not included.

$10 \mathrm{~d}$ in vitro. Using fura-2 ratiometric imaging with a criterion of at least a $20 \mathrm{~nm}$ rise at the time of peptide application, a rise in calcium in response to hypocretin was found in $14 \%$ of 235 cells recorded in five sets of experiments. Addition of hypocretin (1 $\mu \mathrm{M}$ ) evoked a calcium rise that recovered to lower baseline levels after hypocretin washout (Fig. 12A). Some cells showed a stable plateau of calcium during hypocretin activation, and others showed a substantial increase in calcium transients during peptide treatment. Two different peptides may be derived from preprohypocretin, hypocretin 1 and 2 . The response of single neurons to each of the peptides was examined. As a control, a C-terminal 17 -amino acid peptide derived from the preprohypocretin sequence with no expected physiological action was also used. Neurons responded to both hypocretin 1 and hypocretin- 2 with a
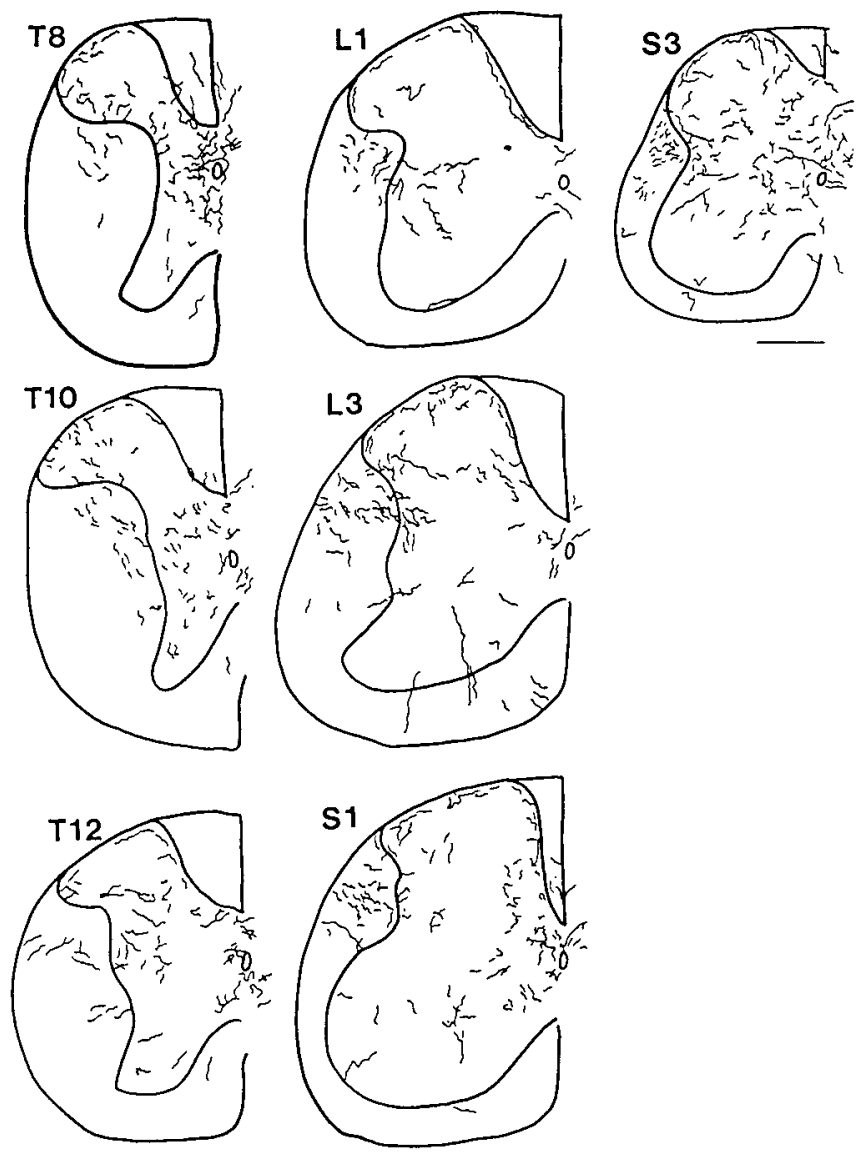

Figure 8. Hypocretin axons in mouse spinal cord, T6-S4. Continuation of the previous figure.

calcium rise but not to the $\mathrm{C}$-terminal control (Fig. 12B) or to stopcock changes in normal buffer. After peptide washout, calcium levels returned to baseline values.

Oxytocin is another hypothalamic peptide that has been described in the spinal cord. Some of the regions of oxytocin innervation in the cord are similar to that for hypocretin. Because the number of oxytocin neurons projecting to the cord from the hypothalamic paraventricular nucleus is greater than the number of vasopressin neurons, which also innervate the cord (Sawchenko and Swanson, 1982), and because oxytocin has been reported to have an excitatory role in the hypothalamus (Theodosis, 1985), the responses of hypocretin were compared with those of oxytocin. The calcium response to hypocretin was compared with equimolar concentrations of oxytocin $(1 \mu \mathrm{M})$ on the same neurons. Almost twice as many cells responded to hypocretin compared with oxytocin (Fig. 12C,D). Of 182 total cells in four sets of experiments, $14.8 \%$ responded to hypocretin, but only $7.6 \%$ responded to oxytocin.

\section{DISCUSSION}

The present study describes for the first time a strong projection from hypocretin-immunoreactive cells in the lateral hypothalamic area to all levels and all laminae of the spinal cord. Although some fibers can be found in all regions of the cord, some regions receive a more substantial and selective innervation. Hypocretin innervation shows similar patterns of innervation in the mouse, 

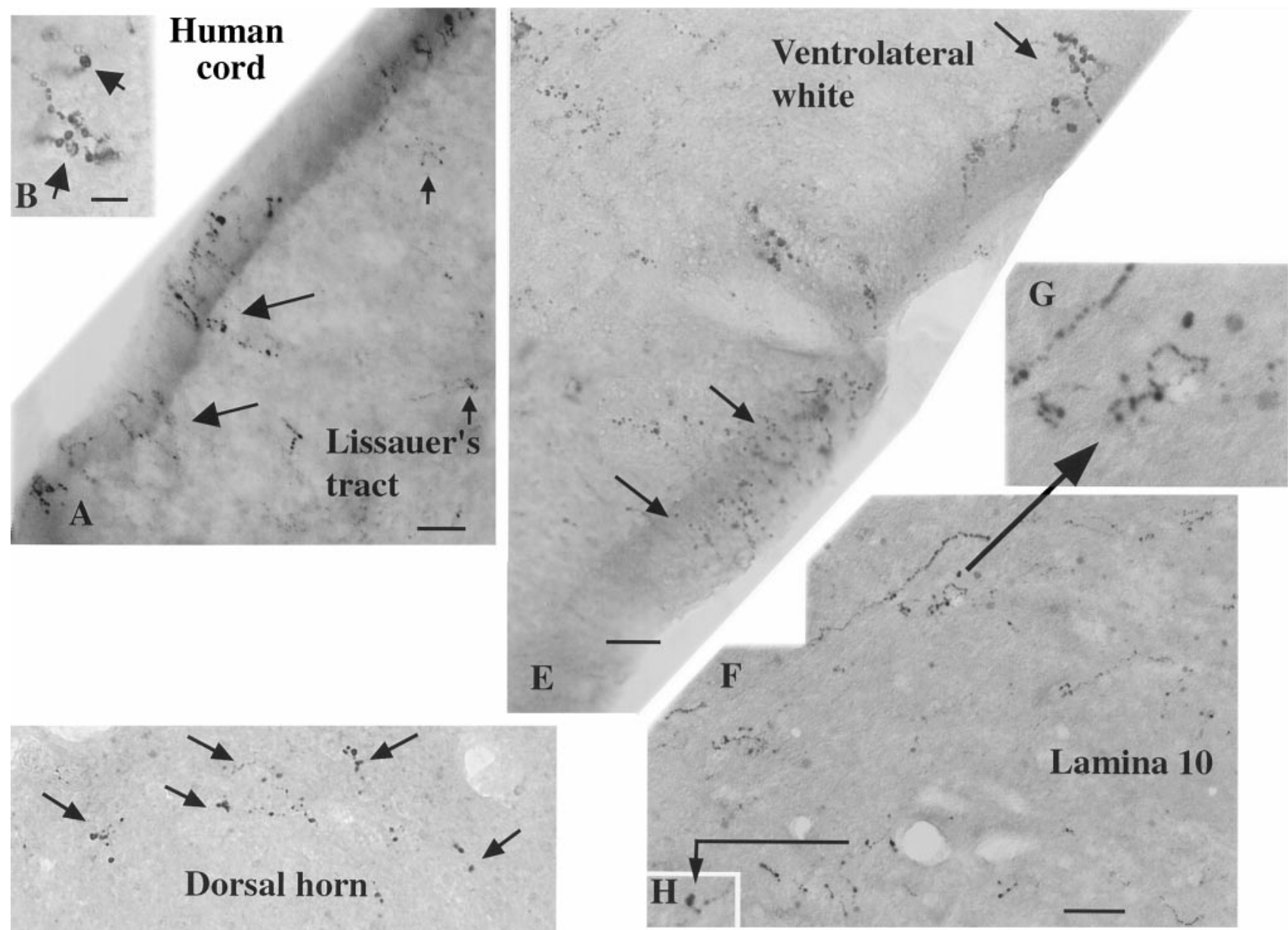
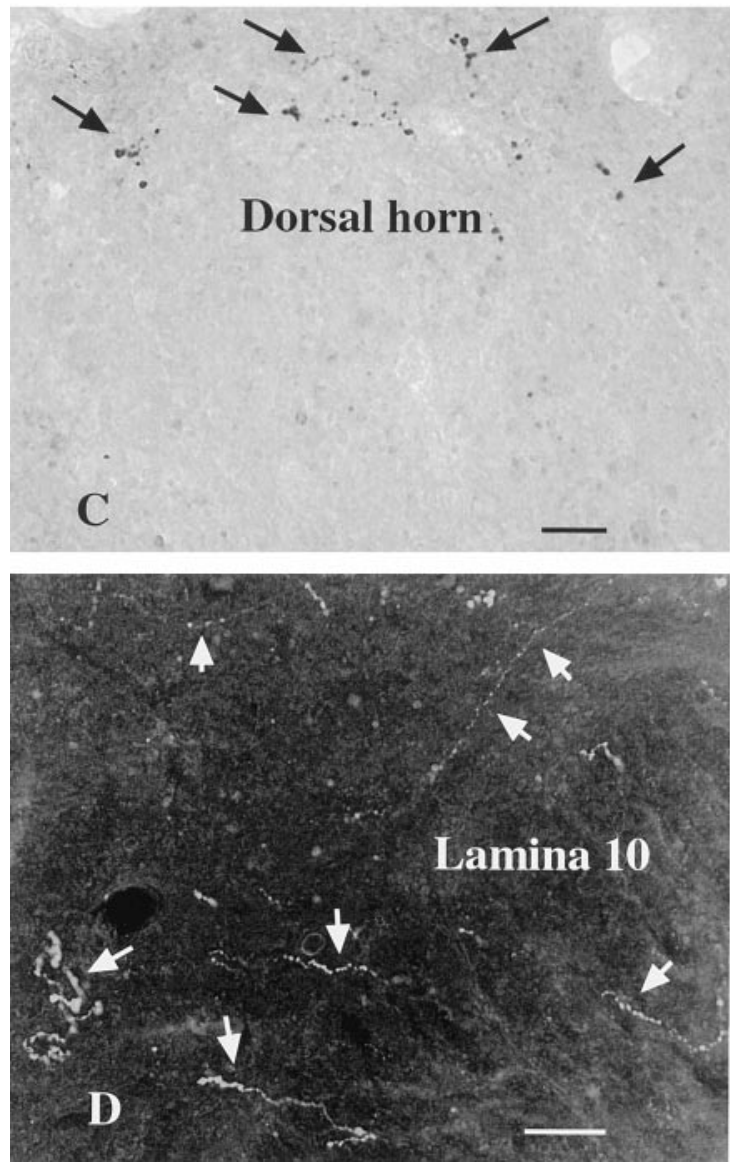

rat, and human, suggesting some functional importance facilitating evolutionary conservation of this tract.

Melanin-concentrating hormone $(\mathrm{MCH})$ is another peptide synthesized by neurons in the same region of the lateral hypothalamus where hypocretin-containing cells are found (Skofitsch et al., 1985; Zamir et al., 1986; Fellmann et al., 1987, 1989). Similar to hypocretin, $\mathrm{MCH}$ has been implicated in the control of feeding behavior (Qu et al., 1996). Although no figures were presented, an $\mathrm{MCH}$ projection to the spinal cord was noted (Bittencourt et al., 1992). This raises the question of whether the 


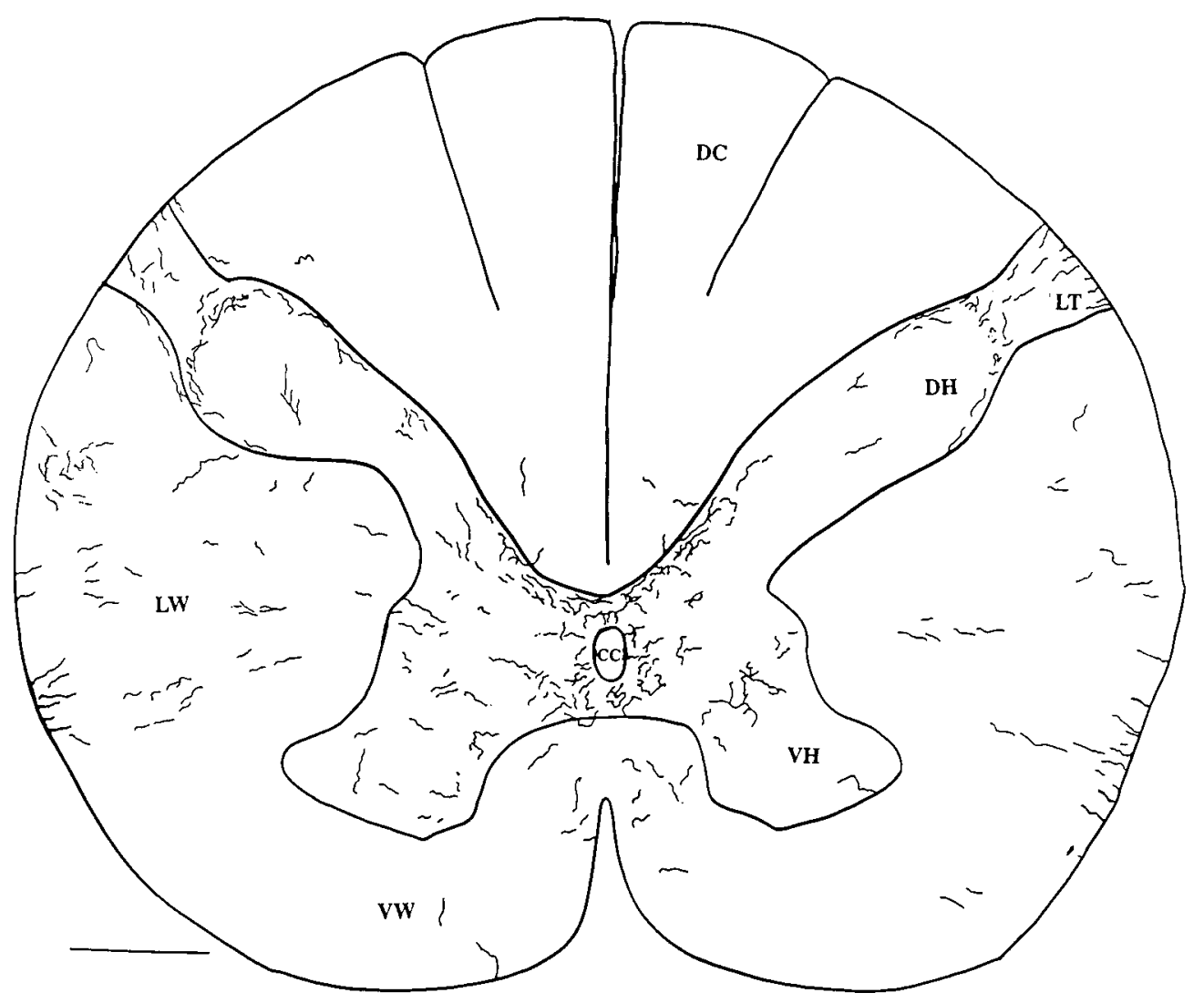

Figure 10. Human cervical spinal cord. Camera lucida drawing was made of hypocretin-immunoreactive axons in two adjacent $40 \mu \mathrm{m}$ sections of a C4-C5 cross-section of a human cord. $D H$, Dorsal horn; $V H$, ventral horn; $D C$, dorsal columns; $c c$, central canal; $L W$, lateral white matter; $V W$, ventral white matter; $L T$, Lissauer's tract. Scale bar, $1 \mathrm{~mm}$. cells that express hypocretin are the same as those that synthesize $\mathrm{MCH}$. Double-labeling studies failed to find any neurons that expressed both peptides, suggesting that in fact the two peptides are found in different populations of neurons (Elias et al., 1998; Peyron et al., 1998). Furthermore, Bittencourt et al. (1992) reported that the $\mathrm{MCH}$ projection to the cord had approximately similar levels of innervation in the marginal zone, substantia gelatinosa, ventral horn, and central gray (Bittencourt and Elias, 1998) and smaller projections to the intermediolateral column. This is in striking contrast to hypocretin, which showed a strong projection to the intermediolateral column, a higher innervation of the central gray than the ventral horn, and a much higher innervation of the marginal zone than of the deeper substantia gelatinosa.

That some neurons were immunoreactive for hypocretin but were not retrogradely labeled with dye transported from the cord could suggest that not all hypocretin-containing neurons project to the spinal cord. An alternate explanation is that not all neurons that send axons to any specific region would necessarily be labeled with retrogradely transported dye, possibly because of damage during dye injection or to small-caliber fibers with limited transport. Some cells showed diamidino yellow labeling but no hypocretin immunoreactivity. These could represent other classes of neurons in the lateral hypothalamus that project to the spinal cord, for instance, the neurons that contain $\mathrm{MCH}$.

\section{Hypocretin function in spinal cord}

What is the physiological role of hypocretin in the spinal cord? This may in part be addressed by examining the role of the lateral hypothalamus in general. It has been implicated in the regulation of feeding (Powley and Keesey, 1970; van den Pol, 1982) and detection of circulating glucose levels (Oomura, 1983). This is consistent with suggestions that hypocretin injections may enhance food intake (Sakurai et al., 1998). Hypocretin may also participate in endocrine regulation (van den Pol et al., 1998).

Spinal cord and other extrahypothalamic projections from the hypothalamus have been described previously, particularly a projection from parvocellular neurons of the paraventricular nucleus that contains oxytocin, vasopressin, and their associated neurophysins (Hancock, 1976; Swanson, 1977; Sofroniew and Weindl, 1978; Hosoya and Matsushita, 1979; Armstrong et al., 1980; Nilaver et al., 1980; Swanson and Sawchenko, 1983; van den Pol and Collins, 1994). These axons innervate the intermediolateral column of the thoracic spinal cord (Swanson, 1977) and also innervate laminae 1 and 10, a partial overlap with the projection from hypocretin axons described in the present study. Although the projection from the paraventricular nucleus has received the most attention within the hypothalamus, the spinal projection from the lateral hypothalamus is greater, based on a larger number of lateral hypothalamus $(\mathrm{LH})$ cells labeled after retrograde dye transport from the cord (Hosoya, 1980). Projections from the paraventricular nucleus (Ono et al., 1978) and LH in general (Saper et al., 1976) have been suggested to be ipsilateral; although this may be a general rule, in the present study hypocretin axons were found crossing the midline particularly in the dorsal region of the central gray (lamina 10) at all levels of the cord. This is particularly striking in the sacral cord where axons cross the midline frequently, suggesting that some LH cells innervate the cord bilaterally. Another point of comparison relates to the response of cervical cord neurons to hypocretin and oxytocin. Twice as many cells responded to hypocretin as to oxytocin, suggesting that more cervical spinal cord cells may express receptors responsive to hypocretin than to oxytocin. Because 

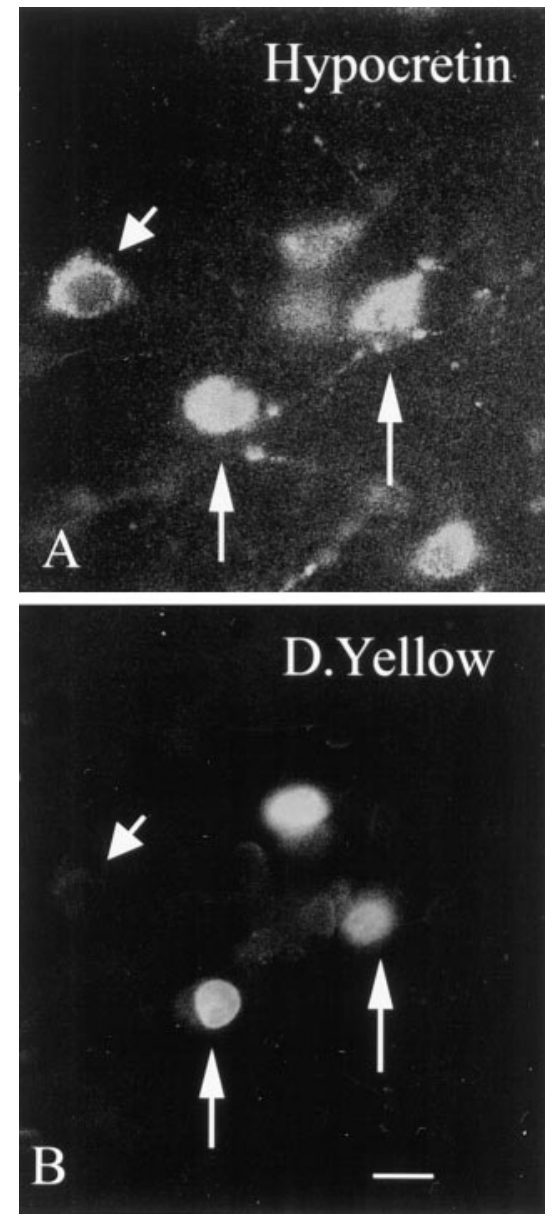

Figure 11. Retrograde transport of tracer to hypocretin-immunoreactive cells in lateral hypothalamus. In the same section, neurons immunoreactive for hypocretin $(A)$ and also labeled with diamidino yellow (D.Yellow) $(B)$ transported from the spinal cord back to the hypothalamus. The two vertical arrows in $A$ and $B$ show hypocretin-immunoreactive neurons in which the nucleus is labeled with diamidino yellow. The short arrowhead shows a hypocretin-immunoreactive neuron in the same field that shows no nuclear labeling for diamidino yellow. Scale bar, $5 \mu \mathrm{m}$.

thoracolumbar neurons receive a strong oxytocin innervation, the relative response to oxytocin and hypocretin may be different in neurons there. Alternately, hypocretin receptors may more closely couple to calcium regulation than do oxytocin receptors.

Based on the innervation patterns of hypocretin in the spinal cord, it appears that the peptide may modulate both the sympathetic and parasympathetic parts of the autonomic nervous system. Innervation of the intermediolateral cell group in thoracic and lumbar cord suggests an involvement in sympathetic regulation. Hypocretin innervation of the nucleus of the solitary tract and dorsal motor nucleus of the vagus (Peyron et al., 1998), coupled with the innervation of the caudal sacral cord described here suggest that a hypocretin may be involved in regulation of the parasympathetic system.

Inferences about hypocretin function can be made on the basis of the laminae in the spinal cord that hypocretin preferentially innervates. The innervation of the marginal zone, lamina 1 , throughout all segments of the cord suggests that hypocretin may be involved in modulation of pain and thermal sensation. Although most of the axons in Lissauer's tract, dorsolateral to the dorsal horn, are primary sensory axons (Chung and Coggeshall,

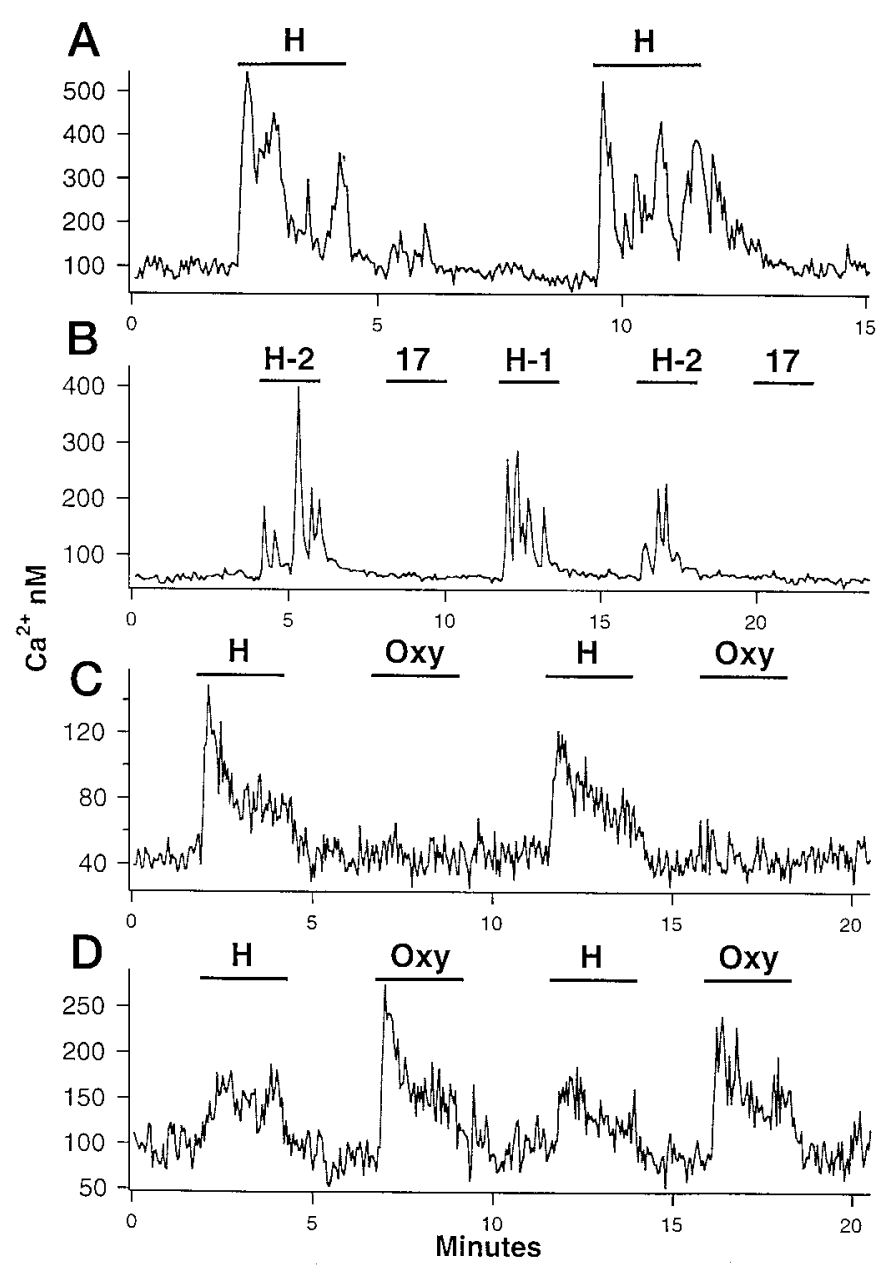

Figure 12. Spinal cord neurons show calcium rise in response to hypocretin. $A$, Hypocretin-2 $(H, 1 \mu \mathrm{M})$ was added by bath perfusion. In the presence of hypocretin, cytoplasmic calcium increased as measured with fura-2 imaging. Horizontal lines mark the presence of the peptide. $B, \mathrm{~A}$ neuron responds both to hypocretin-1 $(H-1)$ and hypocretin-2 $(H-2)$ but not to the 17-amino acid inactive $\mathrm{C}$-terminal fragment (17) of preprohypocretin. $C, D$, In two neurons recorded simultaneously, the response to hypocretin-2 $(H, 1 \mu \mathrm{M})$ and oxytocin $(O x y, 1 \mu \mathrm{M})$ was compared. In $C$, the neuron responds to hypocretin but shows little response to oxytocin. The neuron in $D$ responds to both oxytocin and hypocretin.

1982), hypocretin axons descend here before entering lamina 1. Previous work has shown fine-caliber primary afferents terminating in lamina 1 (Kumazawa and Perl, 1978). Three types of cells in lamina 1 were found in physiological studies: those that respond to mechanical or thermal nociception and a type that responds to both noxious stimuli and non-pain-related temperature changes (Christensen and Perl, 1970). In some sections of the present study, some cells of the marginal zone were surrounded by hypocretin-immunoreactive boutons, with neighboring cells in the same lamina showing no innervation. This suggests that hypocretin fibers selectively innervate subpopulations of neurons in the marginal zone, perhaps either related to a functional sensory modality, such as a c-fiber bearing pain information, or based on specific ascending projections, which have been found innervating the locus coeruleus (Cedarbaum and Aghajanian, 1978) or contributing to the spinothalamic tract (Narotzky and Kerr, 1978). Hypocretin fibers may therefore modulate pain sensation. This is consistent with observations that stimulation of the 
lateral hypothalamus in the region of hypocretin neurons produces pain analgesia (Dafny et al., 1996; Franco and Prado, 1996), raising the interesting question of whether hypocretin might possess antinociceptive properties in the cord.

Some of the same superficial dorsal horn regions innervated by hypocretin axons receive an innervation from oxytocin- or vasopressin-containing fibers from the paraventricular nucleus (Swanson and McKellar, 1979), in contrast to long descending axons from the cortex, which preferentially innervate the deeper layers of the dorsal horn (Brown, 1981). Whereas the paraventricular nucleus is reported to send only a sparse innervation to the sacral cord (Swanson and McKellar, 1979), a large hypocretin projection is found here. This indicates that although there is some overlap between the descending projections from different fiber systems of the hypothalamus to the cord, there also appear to be some substantial differences.

Hypocretin axons with numerous boutons can be found in lamina $X$ around the central canal. Similar to lamina 1, cells here also respond to nociceptive sensory information (Honda and Lee, 1985; Honda and Perl, 1985; LaMotte, 1987) and are also involved in autonomic function. Injections of retrograde dyes into the cord label neurons in the lateral hypothalamus (Veening et al., 1987). Anterograde transport of tritiated substances from injections in the hypothalamus labeled axons terminating in the intermediolateral column of the thoracic cord (Saper et al., 1976). Coupled with the finding of hypocretin innervation of the intermediolateral column of cells, this suggests that hypocretin innervates a number of spinal cord regions that may be involved in autonomic function. This contrasts with the view for other lateral hypothalamic neurons containing a different peptide, $\mathrm{MCH}$, for which only a sparse innervation of autonomic preganglionic regions is reported, leading to the suggestions that the " $\mathrm{MCH}$ system is not apt to play a major direct role in modulating autonomic functions" (Bittencourt et al., 1992).

The fact that some spinal neurons respond to hypocretin application suggests that receptors may be expressed by some subpopulations of neurons. In our earlier physiological studies with whole-cell voltage-clamp recording and digital imaging, we found that hypocretin receptors were located both on the cell body and on axon terminals (van den Pol et al., 1998). The frequency of both glutamate- and GABA-mediated miniature postsynaptic currents was enhanced in the presence of hypocretin, with no change in amplitude, suggesting the presence of presynaptic hypocretin receptors on axon terminals. This raises the interesting and testable hypothesis that hypocretin may modulate sensory information from the primary afferents arising from the dorsal roots and innervating lamina 1 . If so, and if hypocretin actions are similar in the cord, then hypocretin may hypothetically increase the release of the neurotransmitter released by the primary afferents.

\section{General role of hypocretin}

Although projections from hypocretin-containing neurons to the spinal cord have not been previously reported, in more rostral regions of the brain hypocretin-containing axons have been found to selectively innervate a number of brain regions that may play a role in setting a general tone for brain activation or inactivation; this includes a strong innervation of the locus coeruleus and innervation of the dorsal motor nucleus and nucleus of the solitary tract, the raphe, and most regions of the hypothalamus, including regions involved in sleep and temperature regulation in the posterior hypothalamus and preoptic area (de Lecea et al.,
1998; Peyron et al., 1998; van den Pol et al., 1998). Together with the results of the present study demonstrating an innervation of both sympathetic and parasympathetic regions of the autonomic regions of the cord, these results suggest that hypocretincontaining neurons may play a widespread role in setting a general level of activation of a large number of interrelated systems related to the autonomic nervous system. This would include systems regulating energy balances, as suggested by the feeding studies of Sakurai et al. (1998). With this perspective, the enhancement of feeding previously reported could be attributable to a general level of autonomic activation, known to induce a variety of behaviors, including but not restricted to feeding (Smith et al., 1997).

\section{REFERENCES}

Armstrong WE, Warach S, Hatton GI, NcNeill TH (1980) Subnuclei in the rat paraventricular nucleus: a cytoarcitectural, HRP, and immunocytochemical analysis. Neuroscience 206:317-345.

Bittencourt JC, Elias CF (1998) Melanin-concentrating hormone and neuropeptide EI projections from the lateral hypothalamic area and zona incerta to the medial septal nucleus and spinal cord: a study using multiple neuronal tracers. Brain Res 805:1-19.

Bittencourt JC, Presse F, Arias C, Vaughan J, Nahon JL, Vale W, Sawchenko PE (1992) The melanin-concentrating hormone system of the rat brain: an immuno- and hybridization histochemical characterization. J Comp Neurol 319:218-245.

Brown AG (1981) Organization in the spinal cord. The anatomy and physiology of identified neurons, pp 1-238. New York: Springer.

Cedarbaum JM, Aghajanian GK (1978) Afferent projections to the rat locus coeruleus as determined by a retrograde tracing technique. J Comp Neurol 178:1-16.

Christensen BN, Perl ER (1970) Spinal neurons specifically excited by noxious or thermal stimuli: marginal zone of the dorsal horn. J Neurophysiol 33:293-307.

Chung K, Coggeshall RE (1982) Quantitation of propriospinal fibers in the tract of Lissauer of the rat. J Comp Neurol 211:418-426.

Dafny N, Dong WQ, Prieto-Gomez C, Reyes-Vazquez C, Stanford J, Qiao JT (1996) Lateral hypothalamus: site involved in pain modulation. Neuroscience 70:449-460.

de Lecea L, Kilduff T, Peyron C, Gao X-B, Foye PE, Danielson PE, Fukuhara C, Battenberg ELF, Gautvik VT, Bartlett II FS, Frankel WN, van den Pol AN, Bloom FE, Gautvik KM, Sutcliffe JG (1998) The hypocretins: hypothalamus-specific peptides with neuroexcitatory activity. Proc Natl Acad Sci USA 95:322-327.

Elias CF, Saper CB, Maratos-Flier E, Tritos NA, Lee C, Kelly J, Tatro JB, Hoffman GE, Ollmann MM, Barsh GS, Sakurai T, Yanagisawa M, Elmquist JK (1998) Chemically defined projections linking the mediobasal hypothalamus and the lateral hypothalamus area. J Comp Neurol 402:442-459.

Fellmann D, Bugnon C, Risold PY (1987) Unrelated peptide immunoreactivities coexist in neurones of the rat lateral dorsal hypothalamus: human growth hormone-releasing factor 1-37, salmon melaninconcentrating hormone. Neurosci Lett 74:275-280.

Fellmann DC, Bresson JL, Breton C, Bahjaoui M, Rouillon A, Gouget A, Bugnon C (1989) Cloning of cDNA encoding a rat neuropeptide immunologically related to salmon melanin-concentrating hormone. Neurosci Lett 106:23-28.

Forscher P, Kaczmarek L, Buchanan J, Smith SJ (1987) Cyclic AMP induces changes in distribution and transport of organelles within growth cones of Aplysia bag cell neurons. J Neurosci 7:3600-3611.

Franco AC, Prado WA (1996) Antinociceptive effects of stimulation of discrete sites in the rat hypothalamus: evidence for the participation of the lateral hypothalamus area in descending pain suppression mechanisms. Braz J Med Biol Res 11:1531-1541.

Gautvik KM, de Lecea L, Gautvik VT, Danielson PE, Tranque P, Dopazo A, Bloom FE, Sutcliffe JG (1996) Overview of the most prevalent hypothalamus-specific mRNAs, as identified by directional tag PCR subtraction. Proc Natl Acad Sci USA 93:8733-8738.

Grynkiewicz G, Poenie M, Tsien R (1985) A new generation of Ca2+ indicators with greatly improved fluorescence properties. J Biol Chem 260:3440-3450 
Hancock MB (1976) Cells of origin of hypothalamo-spinal projections in the rat. Neurosci Lett 3:179-184.

Honda CN, Lee CL (1985) Immunohistochemistry of synaptic input and functional characterization of neurons nera the spinal central canal. Brain Res 343:120-128.

Honda CN, Perl ER (1985) Functional and morophological features of neurons in the midline region of the caudal spinal cord of the cat. Brain Res 340:285-295.

Horvath TL, Diano S, van den Pol AN (1999) Synaptic interaction between hypocretin (orexin) containing neurons and arcuate nucleus NPY-producing cells in rodent and primate-a new hypothalamic circuit implicated in energy homeostasis. J Neurosci 19:1072-1087.

Hosoya Y (1980) The distribution of spinal projections neurons in the hypothalamus of the rat, studied with the HRP method. Exp Brain Res 40:79-87.

Hosoya Y, Matsushita M (1979) Identification and distribution of the spinal and hypophyseal projection neurons in the paraventricular nucleus of the rat. A light and electron microscopic study with the horseradish peroxidase method. Exp Brain Res 35:315-331.

Kumazawa T, Perl ER (1978) Excitation of marginal and substantia gelatinosa neurons in the primary spinal cord: indications of their place in dorsal horn functional organization. J Comp Neurol 177:417-434.

LaMotte C (1987) Vasoactive intestinal polypeptide cerebrospinal fluid contacting neurons of the monkey and cat spinal central canal. J Comp Neurol 258:527-541.

Molander C, Xu Q, Grant G (1984) The cytoarchitectonic organization of the spinal cord in the rat. I. The lower thoracic and lumbosacral cord. J Comp Neurol 230:133-141.

Molander C, Xu Q, Rivero-Melian C, Grant G (1989) The cytoarchitectonic organization of the spinal cord in the rat. II. The cervical and upper thoracic cord. J Comp Neurol 289:375-385.

Narotzky RA, Kerr FWL (1978) Marginal neurons of the spinal cord: types, afferent synaptology, and functional considerations. Brain Res 139:1-20.

Nilaver G, Zimmerman EA, Wilkins J, Michaels J, Hoffman D, Silverman A-J (1980) Magnocellular hypothalamic projections to the lower brain stem and spinal cord of the rat. Neuroendocrinology 30:150-158.

Obrietan K, van den Pol AN (1997) GABA-B receptor mediated inhibition of GABA-A receptor calcium elevations in developing hypothalamic neurons. J Neurophysiol 79:1360-1370.

Ono T, Nishino H, Kazuo S, Muramoto K, Yano I, Simpson A (1978) Paraventricular nucleus connections to spinal cord and pituitary. Neurosci Lett 10:141-146.

Oomura Y (1983) Glucose as a regulator of neuronal activity. Adv Metab Disord 10:31-65.

Peyron C, Tighe DK, van den Pol AN, de Lecea L, Heller HC, Sutcliffe JG, Kilduff TS (1998) Neurons containing the novel hypothalamic peptide hypocretin (orexin) project to multiple neuronal systems. J Neurosci 18:9996-10015.

Powley TL, Keesey RE (1970) Relationship of body weight to the lateral hypothalamic feeding syndrome. J Comp Physiol Psychol 70:25-36.

Qu D, Ludwig DS, Gammeltoft S, Piper M, Pelleymounter MA, Cullen MJ, Mathes WF, Przypek J, Kanarek R, Maratos-Flier E (1996) A role for melanin-concentrating hormone in the central regulation of feeding behaviour. Nature 380:243-247.

Rexed B (1952) The cytoarchitectonic organization of the spinal cord in the cat. J Comp Neurol 96:415-466.

Rexed B (1954) A cytoarchitectonic atlas of the spinal cord in the cat. J Comp Neurol 100:297-380.

Sakurai T, Amemiya A, Ishii M, Matsuzaki I, Chemelli RM, Tanaka H, Williams SC, Richardson JA, Kozlowski GP, Wilson S, Arch JRS, Buckingham RE, Haynes AC, Carr SA, Annan RS, McNulty DE, Liu
WS, Terrett JA, Elshourbagy NA, Bergsma DJ, Yanagisawa M (1998) Orexins and orexin receptors: a family of hypothalamic neuropeptides and $\mathrm{G}$ protein-coupled receptors that regulate feeding behavior. Cell 92:573-585.

Saper CB, Loewy AD, Swanson LW, Cowan WM (1976) Direct hypothalamo-autonomic connections. Brain Res 117:305-312.

Sawchenko PE, Swanson LW (1982) Immunohistochemical identification of neurons in the paraventricular nucleus of the hypothalamus that project to the medulla or spinal cord in the rat. J Comp Neurol 205:260-272.

Skofitsch G, Jacobowitz DM, Zamir N (1985) Immunohistochemical localization of a melanin concentrating hormone-like peptide in the rat brain. Brain Res Bull 15:635-649.

Smith WJ, Stewart J, Pfaus JG (1997) Tail pinch induces fos immunoreactivity within several regions of the male rat brain: effects of age. Physiol Behav 61:717-723.

Sofroniew M, Weindl A (1978) Extrahypothalamic neurophysin containing perikarya, fiber pathways, and fiber clusters in the rat brain. Endocrinology 102:334-337.

Swanson LW (1977) Immunohistochemical evidence for neurophysincontaining autonomic pathway arising in the paraventricular nucleus of the hypothalamus. Brain Res 128:346-353.

Swanson LW, McKellar S (1979) The distribution of oxytocin- and neurophysin-stained fibers in the spinal cord of the rat and monkey. J Comp Neurol 188:87-106.

Swanson LW, Sawchenko PE (1983) Hypothalamic integration: organization of the paraventricular and supraoptic nuclei. Annu Rev Neurosci 6:269-324.

Theodosis DT (1985) Oxytocin-immunoreactive terminals synapse on oxytocin neurones in the supraoptic nucleus. Nature 313:682-684.

Truex RC, Carpenter MB (1969) Human neuroanatomy, pp 1-637. Baltimore: Williams \& Wilkins.

van den Pol AN (1982) Lateral hypothalamic damage and body weight regulation: role of gender, diet, and lesion placement. Am J Physiol 242:R265-R74.

van den Pol AN (1985) Silver-intensified gold and peroxidase as dual ultrastructural immunolabels for pre- and postsynaptic neurotransmitters. Science 228:332-335.

van den Pol AN, Collins WC (1994) The paraventriculo-spinal tract as a model for axon injury spinal cord. J Comp Neurol 349:244-258.

van den Pol AN, Obrietan K, Chen G, Belousov AB (1996) Neuropeptide Y-mediated long-term depression of excitatory activity in suprachiasmatic nucleus neurons. J Neurosci 16:5883-5895.

van den Pol AN, Gao XB, Obrietan K, Kilduff TS, Belousov AB (1998) Pre- and postsynaptic actions and modulation of neuroendocrine neurons by a new hypothalamic peptide, hypocretin/orexin. J Neurosci 18:7962-7971.

Veening JG, Te Lie S, Posthuma P, Geeraedts LMG, Nieuwenhuys R (1987) A topographical analysis of the origin of some efferent projections from the lateral hypothalamic area in the rat. Neuroscience 22:537-551.

Wijker M, Wszolek ZK, Wolters ECH, Rooimans MA, Pals G, Pfeiffer RF, Lynch T, Rodnitzky RL, Wilhelmsen KC, Arwert F (1996) Localization of the gene for rapidly progressive autosomal dominant parkinsonism and dementia with pallido-ponto-nigral degeneration to chromosome 17q21. Hum Mol Genet 5:151-154.

Wilhelmsen KC, Lynch T, Pavlou E, Higgens M, Hygaard TG (1994) Localization of disinhibition-dementia-parkinsonism-amyotropy complex to 17q21-22. Am J Hum Genet 55:1159-1165.

Zamir N, Skofitsch G, Bannon MJ, Jacobowitz DM (1986) Melaninconcentrating hormone: unique peptide neuronal system in the rat brain and pituitary gland. Proc Natl Acad Sci USA 83:1528-1531. 